\title{
The Problems of the Military Provisions and Payouts and Their Consequences during the Upper Hungary Campaign of 1664
}

\author{
ZOLTÁN IGOR KOMJÁTI
}

\section{Private researcher, Abasár, Hungary}

Abstract: This study concentrates on the financial and alimentative problems of the Anti-Turkish Campaign of Upper Hungary in 1664, and on the military abuses derived from the shortage of the adequate supplying. Due to the often happening contemporary logistic shortages and the exiguousness of the Hungarian resources, the Imperial War Council supplied with difficulty the German-Hungarian Army led by General Louis de Souches and Stephen I. Koháry, General-Captain of Fil'akovo (who was commissioned twice to Commander of the Hungarian Troops during the campaign). The obtaining of the payout was always on the agenda in the agreements with the county magistrates, and by order of Palatine Francis Wesselényi, the magnates and the prelates were also obliged to surrender grain crops and other foods. In spite of the very often shortage of supplying, the commanders managed to solve the problems, and the Christian Army successfully re-captured Nitra and Levice, and were also victorious on the battlefield of Žarnovica and Hronský Beňadik. But the encamped soldiers were encouraged by the unsystematic paying and food supplying to pillage the inhabitants of the surrounding settlements. The campaign also gave an opportunity for the looting of the vagrant soldiers who often could not be called to account for their crimes, because they did not serve under the banners. To avoid the pillages and atrocities, the only solution was that trusted and disciplinable soldiers were recruited in the camp, and by means of issuing strict orders, the commerce of the stolen livestock were forbidden in all of free and royal towns. The magistrates of certain settlements and other owners asked for safe-conduct or safeguard garrison from the commanders trying to assure the protection for the inhabitants and their belongings.

Keywords: Military Provisions, Hungarian-Ottoman conflict, Upper Hungary, early modern period.

DOI: https://doi.org/10.24040/ahn.2021.24.01.70-95

The Austro-Ottoman conflict in the beginning of the 1660s had a traumatic effect on the contemporary Hungarian society, as the well-arranged peace treaties from 1606 enabled to avoid the stationing of the Ottoman Empire's main forces in Hungary. The as before sceptical and distrusting Hungarian society had to learn with dismay that three years after the loss of Oradea, one of the most important strategical fortress defending Vienna, fortress of Nové Zámky (German: Neuhäusel) fell into 
The problems of the military provisions and payouts and their consequences ...

Ottoman hands on early autumn of $1663 .{ }^{1}$ Nevertheless, the Ottoman Supreme War Council decided to transfer the main war theatre to the south-western part of the Transdanubian Region, as Nicholas Zrínyi was regarded more dangerous enemy, who with his brave and ingenious deeds of valour (for example: the Winter Campaign toward Osijek in the beginning of 1664) almost annihilated the result of the successful siege of Nové Zámky. The Hungarian historiography has paid little attention to the before-mentioned war theatre of the War of $1663-1664 .^{2}$

But the events of the Upper Hungary Campaign must be analysed at the regional level, even if the historiographers regard them as happenings in an extension war theatre and do not research and elaborate exactly this theme. In my present study, I try to fill a gap and contribute to the description of the history of the Upper Hungary Campaign of 1664 , presenting some day to day action of the non-war activities of the campaign. ${ }^{3}$

\section{The supplies: in provisions and payouts}

Howsoever Leopold the First and the Court War Council planned well the Campaign of 1664, they could not exactly ensure the financial basis of the soldiers' payouts during the first part of the operations. Observing his encamped, but unpaid soldiers' discontent, Stephen I. Koháry (1616 - 1664) encouraged to inquire about the payouts from one of the attendant of the Wesselényi Family, Michael Bory, Provisor and Mustermaster of the Hungarian Forces. Michael Bory replied to Koháry on $11^{\text {th }}$ of March, that his letter - concerning the subordinacy and superordinacy and the payouts - had been forwarded to Palatine Francis Wesselényi.

\footnotetext{
${ }^{1}$ Magyarország történeti kronológiája. II. kötet (1526-1848). Budapest : Akadémiai Kiadó, 1982. 483.

2 ÁGOSTON, Gábor - OBORNI, Teréz: A tizenhetedik század története (Magyar Századok sorozat). Budapest : Pannónia Kiadó, 2000. 198-200; NAGY, László: Hajdúvitézek (15911699). Budapest : Zrínyi Katonai Kiadó, 1983. 272-277; NAGY, László: „....Megfogyva bár, de törve nem..." Török háborúk viharában (1541-1699). Budapest : Tankönyvkiadó, 1990. 209-222; Magyarország története 3/2. (1526-1686). Ed. by Zsigmond Pál Pach. Budapest : Akadémiai Kiadó, 1985. 1122-1132; Magyarország hadtörténete I. Ed. by Ervin Liptay. Budapest : Zrínyi Katonai Kiadó, 1984. 284-288; R. VÁRKONYI Ágnes: A rejtőzködő Murányi Vénus (Labirintus sorozat). Budapest : Helikon Kiadó, 1987. 124-194; PÉTER, Katalin: A magyar romlásnak századában (Magyar História sorozat). Budapest: Gondolat Kiadó, 1979. 154-179; PERJÉS, Géza: Zrínyi Miklós és kora. Budapest: Osiris Kiadó, 2002. 340-418.

3 The name „Upper Hungary Campaign" is not consistent, and the history literature does not give an answer the reason why of this name, albeit the main battles and military operations took place by near the Hron River, and this part of country was named „Lower Hungary" by the contemporaries. I expect so: as the main war theatre of the 1664 year was situated in the south-western part of the Transdanubian Region, the historians correlated to that, thus every parts of country situated by north from the Danube River had got the „Upper” prefix. - Z.I.K.
} 
According to the Palatine's decision, Captain Stephan Szobonya and another captain named Battik were reassigned to the troops being under Koháry's command. And what concerns the payouts: the German Muster-master was in the Camp near Nitra, but he would be back to Banská Bystrica by $14^{\text {th }}$ of March. In other respects, the Muster-master of Košice was responsible for the arranging of the payouts of the Hungarian troops called to arms and rallied by the Mining Towns. Bory suggested that Koháry would rapidly write to the Palatine Wesselényi so as he would make a decision about the payouts of the soldiers at the earliest possible moment, because the monies disbursing from the Exchequer would be easily distributed among other troops. But if the Palatine's favourable reply would arrive to Michael Bory till $14^{\text {th }}$ of March, he would start the paying. Recently, he is able to deal with the payouts of 150 foot-soldiers, because the Counties offered the necessary money being enough for their payouts (implied the earlier promised down payment of 1-1 forints). Finally, Bory asked Koháry to pay particular attention to the cooperation with the Counties, because they have the only reliable pecuniary resources which would bear a hand for the payouts of the soldiers: „...I beg Your Eminency to do your best for the good relationships and remaining of the Counties, because we will all perish, if we will wait for money from other resources, and will not open our eyes on our own..."4 The abovementioned Muster-master did not arrive to Banská Bystrica by $14^{\text {th }}$ of March. So Michael Bory wrote only, that the soldiers were really impatient due to the lack of the payouts, and as the Muster-master would approach to the Mining Town and the day of muster would be fixed, he would immediately inform Koháry. ${ }^{5}$

There was a consultation about the arrangement of the payouts held by General Louis de Souches, John Andrew Joanelli, the Count of Mining Chamber of Banská Štiavnica, and Michael Bory right after the beginning of the Siege of Nitra on $16^{\text {th }}$ of April, but they could not carry out any substantive decision. ${ }^{6}$

Michael Bory, doing his duty conscientiously, presented the arisen defectiveness to Palatine Francis Wesselényi in the Castle of Teplička nad Váhom on the $24^{\text {th }}$ of April, which was very actual, because the Siege

\footnotetext{
${ }^{4}$ National Archives of Hungary - State Archive, Budapest (MNL-OL), Microfilm Department (original archival sources deposited in: State archive, Banská Bystrica, Slovakia, Fund of Koháry-Coburg Family), C 1294 th roll № 15525, (ŠABB, Archive of the Koháry Family, Pars V.), Michael Bory's letter to Stephen Koháry (Banská Bystrica, 11 th of March, 1664).

${ }^{5}$ MNL-OL C $1287^{\text {th }}$ roll № 14375, (ŠABB, Archive of the Koháry Family, Pars V.), Michael Bory's letter to Stephen Koháry (Banská Bystrica, $15^{\text {th }}$ of March, 1664).

${ }^{6}$ MNL-OL E $199,6^{\text {th }}$ box, $25^{\text {th }}$ pallium, fol. 6, Archivum familiæ Wesselényi $(1583-1732)$, Louis de Souches's letter to Francis Wesselényi (Imperial Camp by Nitra, 16 $6^{\text {th }}$ of April, 1664): „...Modum solutionis cum eodem Dominus Bory et Dominus Joanelli iam conclusimus...”.
} 
The problems of the military provisions and payouts and their consequences ...

of Nitra had been almost started for more than a week. The Palatine wrote to Koháry who took part in the siege with his troops that he would not worry about his own and his soldiers' payout, because though there would not be too much chance for the immediate paying, but the Palatine would request audience from the Sovereign Leopold the First, and he would try to expedite the arranging of the payout in all manner of ways. ${ }^{7}$

The putting up of the soldiers' payout was continuing. Michael Bory wrote the Palatine on $1^{\text {st }}$ of May, that soon he would go to Banská Štiavnica, Krupina and Bzovík so as to conciliate with the Mining Towns and Hont County about the distribution of that amount of money which in principle had been assigned by the Chamber of Spiš Region by the request of Palatine Wesselényi. ${ }^{8}$

During his staying in the Imperial Camp by Nitra, Stephen Koháry, the Commander-in-Chief of the Hungarian troops, also complained to the Palatine about the default of his 400 Forints payout: „...Indeed, My Lord, it is only impossible for my wretched staying in here without any payouts! Your Eminency deign to write to the General [=Louis de Souches] so as to arrange my 400 forints as promised earlier! But there are lot of money by him which is said to be appropriated for military purposes. I will do my best for Our Country such as others who are staying here at their leisure, but my present unpaid "shepherding" I will not bear any longer! I do not envy nobody that "honour" in which now I am! I beg for Your Eminency to give me answer: will I have a payout? otherwise I will immediately left this position, as I never offered myself for this before at all!..." Sometime in the middle of May, the Hungarian mounted soldiers separated from the Imperial troops, and moved to Vel'ké Uherce and its surroundings. Several soldiers had left the Hungarian camp, but a certain part of them lasted due to the enticing promise of the Palatine that they would get their payout within two weeks. As it was delayed, the soldiers asked Koháry to write a letter to the Palatine. He did so, and developed that he was hardly able to keep them under control, because they were always grumbling about the payout every day since already the camping near Pukanec, and only contented themselves with the promise of monthly 2 forints so far, because Koháry threatened them, that they would incur the Palatine's displeasure in case of their leave from the camp, and there would not be any place for them to hide from his retaliatory measurements. For avoiding

\footnotetext{
${ }^{7}$ MNL-OL C 1294th roll № 15398, (ŠABB, Archive of the Koháry Family, Pars V.), Francis Wesselényi's letter to Stephen Koháry (Teplička nad Váhom, 25 th of April, 1664).

${ }^{8}$ MNL-OL E 199, $4^{\text {th }}$ box, $16^{\text {th }}$ pallium, fol. 6-7, Archivum familiæ Wesselényi (1583-1732), Michael Bory's letter to Francis Wesselényi (Banská Bystrica, $1^{\text {st }}$ of May, 1664).

${ }^{9}$ MNL-OL E $199,4^{\text {th }}$ box, $61^{\text {st }}$ pallium, fol. 7-8, Archivum familiæ Wesselényi (1583-1732), Stephen Koháry's letter to Francis Wesselényi (Imperial Camp by Nitra, 26 $6^{\text {th }}$ of April, 1664).
} 
the further deteriorate of the remained Hungarian soldiers' moral and combativity, Koháry asked the Palatine that he would order them to a certain place, where he would personally take muster of the troops, or send Michael Bory with the payout to them. He would choose either, he would dispatch as soon as possible - the Commander-in-Chief urged Wesselényi. ${ }^{10}$

Nevertheless, the disbursement of the general payout did not realize within one month after retaking of Nitra. On 31 st of May, Michael Bory went to Kremnica and Banská Bystrica so as to concert with the Mining Towns about the financing. He promised that he would report upon the results before the Palatine on $2^{\text {nd }}$ of June in Zvolen, but he particularly asked that the Palatine would make Stephen Koháry stay there: “...It would be very good, if Koháry His Eminency would await me, and we would be conferring with each other about the orders, circumstances, payouts and other military problems, before Your Emincency make a decision about the military operations..."11

By the morning of $1^{\text {st }}$ of June, Michael Bory slept in Banská Bystrica, and when he was informed that Stephen Koháry really stayed by the Palatine, he wrote to him that he would not leave the residence of the Palatine while he would arrive to him on $2^{\text {nd }}$ of June, by 7 o'clock morning. He did the best to the full extent of his ability for the obtaining of the payout, but it would be crucial that Bory would communicate with both Koháry and the Palatine, so he almost begged him that the Commander-in-Chief would put aside the ordered military jobs, while he would not confer to each other. Bory was aware of the fact, that General de Souches had already ordered Koháry and his troops to march toward Levice, which was deprecated by him, because it would be no worth launching offensive with the Hungarian soldiers while they would get their payout, and the events of the last weeks were good examples for that. In Bory's opinion, the military operations would be postponed with few days, because the obtaining of the payout would be arranged within few days, and the sum of Koháry was already available. ${ }^{12}$

\footnotetext{
${ }^{10}$ In the same place. fol. 13-14, Stephen Koháry's letter to Francis Wesselényi (Vel'ké Uherce, $26^{\text {th }}$ of May, 1664).

${ }^{11}$ MNL-OL E 199, $4^{\text {th }}$ box, $16^{\text {th }}$ pallium, fol. 8-9, Archivum familiæ Wesselényi (1583-1732), Michael Bory's letter to Francis Wesselényi (Žiar nad Hronom, 31 st of May, 1664).

${ }^{12}$ MNL-OL C 1298 $8^{\text {th }}$ roll № 16159, (ŠABB, Archives of the Koháry Family, Pars V.), Michael Bory's letter to Stephen Koháry (Banská Bystrica, $1^{\text {st }}$ of June, 1664). Michael Bory explained the expediency of the waiting of the payout so: „...I know, that the General [=Louis de Souches] has launched the operations and the Hungarian soldiers also have to take up arms. This operation would be no effective without the Hungarian troops, but the presence of them would be impossible without payout! The Imperials will come off badly, if they want the assistance of them now. Even if the operation would be postponed with only one day, it would be
} 
The problems of the military provisions and payouts and their consequences ...

But nor Stephen Koháry still did not get his payout, nor all of his soldiers. On $8^{\text {th }}$ of June, he wrote a letter to the Palatine, that they were always grumbling, which is very dangerous, as the siege of Levice had already started. The other problem was that the sum for the payout of the soldiers were already enough for only 1,000 men, but the full-complement is more than that. Two days later Koháry wrote anew to Francis Wesselényi, and developed the problem mentioned in the earlier letter: as the number of the soldiers was above 1,000 persons, there was a lack of 112 forints. Koháry's annoyance had also been grown, because the Mustermaster had wanted to ease his own task, and he had settled the money for only one company, and he had entrusted the distribution of the payout to the Commander-in-Chief. Cavalry captain Stephen Szobonya and another officer named Battik had not got payout since the military operations had been launched, so Koháry had tried to fight 100-100 forints out for them, but it had been failed. The Muster-master had promised 50 forints for a third officer named Révai, but only at that time, if John Rottal would be back to the camp. Koháry had thought that there would be enough money for his payout when Rottal would arrive, because however Michael Bory laboured with great endeavouring, he gained almost no amount of money from the Counties. Koháry had such only easement, that he had got the payout after his General-Captaincy of Fil'akovo (truly, first since 1657!), but, essentially, that did not solve his trouble, because it had been paid in cloth in greater part, whose he would not purchase with no clear profit. Now he was feeding from a slaughtered cow, used his own money brought along from home, and he was very sad, that he could not exactly take care of his own family's alimentation staying in Čabrad' and Sitno. ${ }^{13}$

By the end of June, the problem of the payout was not arranged yet at all. This time Paul Némethy informed Koháry, that he had personally seen Michael Bory and John Rottal about the payout of his commandership several times, but they had only said, that they would take care of both the delayed and the future moneys of Koháry and his soldiers, and, allegedly, Rottal would leave the sum by someone at Banská Bystrica. (Paul Némethy also informed the Commander-in-Chief, that he would get not only his payout, but also the favour of the Sovereign would emanate over him in a little while, as if an anticipation the renewing of his commission of commandership). ${ }^{14}$

worth starting with satisfied and contented Hungarian soldiers. But if Your Eminency will not stay there for my sake, it will be heavy aftermaths to the future..."

${ }^{13}$ MNL-OL E 200, 11 $1^{\text {th }}$ sheaf, 32nd item, fol. 5-6, Acta Diversarum Familiarum 1527-1867, Stephen Koháry's letter to Francis Wesselényi (Imperial Camp by Levice, 10 ${ }^{\text {th }}$ of June, 1664).

${ }_{14}$ MNL-OL C 1294th roll № 15420, (ŠABB, Archive of the Koháry Family, Pars V.), Paul Némethy's letter to Stephen Koháry (Banská Bystrica, 28 ${ }^{\text {th }}$ of June, 1664). 


\section{Zoltán Igor Komjáti}

It seems that the arrangement of the payout of certain Hungarian units could be taken over by a nobleman whose demesne was billeted. A Hungarian mounted unit of 100 under the command of Stephen Szobonya stayed in the demesne of Bysterec ${ }^{15}$ of an unknown countess. On $2^{\text {nd }}$ of July, John Mednyánszky, the Land-Stewart of the demesne, would like to give them the payout of June, as Stephen Koháry had ordered it, and it had also been approved by his landlady. A sum of 4 Hungarian forints had been assigned for each soldier, but the landlady had found the payout of the officers and non-commissioned-officers too high, because she had thought those were double than would be due to them. So she had ordered Mednyánszky to pay that sum for them accustomed in Bratislava County, namely, 25 forints for the lieutenant, 12 forints and 30 denarii for the second-lieutenant, 6 forints for the sergeant, 4 forints for the ensign. The cavalry officers resented the decision, especially Stephen Szobonya, moreover, the private soldiers also wanted the payout of July would be paid for them immediately by Mednyánszky. Szobonya also pronounced that he would not receive the payouts of his soldiers, until the officers and non-commissioned-officers will get the originally promised sums, namely the double of the landlady's offering. Mednyánszky did not take Szobonya's word into consideration, and wrote to Koháry that he was a subject to the countess, and whatever she orders, he would fulfill obediently. If the landlady ordered him to give them the higher payouts, or give also the payout of July for the private soldiers, he would immediately obey to her, but until such an order would not arrive, he would pay only that sum ordered by his landlady, and the payout of July would be paid in August. Thus, Mednyánszky asked Koháry for the arranging of the disagreement that he and the Palatine would also write to the landlady whether she agree with a higher payout for the soldiers, and simultaneously would send him a draft about the amounts of that payout being accustomed in the surrounding counties for his comparison. (It is cleared by the postscript of this letter that Szobonya accepted the reduced amounts, and he also took his soldiers' payout away on that day.) ${ }^{16}$

The exchange ratio also caused problem another time. Some free heyducks encamped near Vel'ké Uherce got their payout from Nicholas Bercsényi senior, but they did not received the fixed sum, because less money had been transported to the camp. From that money was also to be settled the officers' payout, so a reduced sum was handed over to the soldiers, which was very unpleasant for the free heyducks, because the

\footnotetext{
15 Formerly, Bysterec consisted of Malý Bysterec and Vel'ký Bysterec. Nowadays, they are quarters of a town of Dolný Kubín.

${ }_{16}$ MNL-OL C 1294 th roll № 15420, (ŠABB, Archive of the Koháry Family, Pars V.), John Mednyánszky's letter to Stephen Koháry (Bysterec, $2^{\text {nd }}$ of July, 1664).
} 
The problems of the military provisions and payouts and their consequences ...

paid money was worth lesser due to the exchange ratio accustomed throughout in North-Western Hungary. ${ }^{17}$

Curiously, the Magistrate of Bratislava County did not like that the Palatine directed the payout of those soldiers billeted into the County. George Lippay, the Archbishop of Esztergom and temporary Lord-Lieutenant of the County, suggested the Magistrate that though they would write a letter of indignant to the Palatine, but it would be worth their accepting the money and distribute among the armed persons because it would also solve the payout of that soldiers recruited by the County. ${ }^{18}$

It might occur that Hungarian soldiers sold their own horses in order to earn a bare living. During the Siege of Nitra, the afore-mentioned Hungarian cavalry officer Stephen Szobonya promised an Imperial cavalry officer named Neuwirth that he would sell one of his horses. Neuwirth had given advance money to Szobonya, because he had not had the total sum by him. But he did not get the horse, because the Hungarian and Imperial Troops was split after the siege, moved from each other to the remoter places, and the two captains were not able to come across. Neuwirth would like to get the mentioned horse as far as possible, so he asked Koháry that he would bring Szobonya to give the animal to him after the cash down. ${ }^{19}$

The payout could be not only settled for the encamped soldiers, but also to the garrisons of the border castles or fortresses. On the strength of letters coming from Fil'akovo and dated from $21^{\text {st }}$ of April, it turns out that the border soldiers rather got impatient. Martin Unger, the DeputyCaptain, wrote to Stephen Koháry that a pretty much part of the border soldiers were inside the walls: they were making forays throughout the Occupied Territories, ruled by the Turks, and were seeking for loots. Another part of the Garrison of Fil'akovo about Easter almost accepted the offer of the recruiting agent of Šariš County who promised 5 forints per month. The deal failed, because Unger expulsed the recruiter-agent out of the fortress. Stephen Oroszlány, the Military Judge, gave the patent of

17 MNL-OL E $199,4^{\text {th }}$ box, 61 ${ }^{\text {st }}$ pallium, fol. 13-14, Archivum familiæ Wesselényi (15831732), Stephen Koháry's letter to Francis Wesselényi (Vel'ké Uherce, 26 ${ }^{\text {th }}$ of May, 1664). 18 MNL-OL E 199, $5^{\text {th }}$ box, $65^{\text {th }}$ pallium, fol. 166-167, Archivum familiæ Wesselényi (15831732), George Lippay's letter to Francis Wesselényi (Bratislava, 20 $0^{\text {th }}$ of May, 1664).

${ }^{19}$ MNL-OL C 1295 th roll № 15569, (ŠABB, Archive of the Koháry Family, Pars V.), Neuwirth Imperial Captain's letter to Stephen Koháry (Žiar nad Hronom, 24 ${ }^{\text {th }}$ of May, 1664): „...Sperabam quidem ante discessum Illustrissimæ Dominationis Vestræ cum militia Hungarica Equum istam a Domino Capitaneo Sobonÿak juxta promissum ipsius, pro pretio debito me adepturum fore; Cum vero ratione celeritatis itineris procul dubio, præfatus Dominus Capitaneus Sobonÿak mecum convenire non potuit. Eodem causa Illustrissimum Dominationem Vestram lineolis hisce humillime requirere volui, quatenus si alias possibilitas permittit, summam mihi in gratiam dicto Domino Capitaneo Soboniak persuadere velit, ut pro parata pecunia equum istum cognotum mihi permittere dignaretur...". 
recruiting to five officers of Fil'akovo, but they had no money for the recruiters at all, so nobody wanted to enlist under the banner of them. Several free heyducks and foot-soldiers left the fortress, and who remained inside the walls, Unger could detain only with promise of the forthcoming payout. ${ }^{20}$ Francis Újlaky, the Castellan of Filakovo, wrote the following text to the General-Captain: „....Here the Garrison of this place is very decreased. The three Lieutenant and me always rotate the monitoring of the watchers of the gates, and the watchers will be run short, if Your Eminency shall not send some payout for them...". He also wrote that if Koháry would not give any money for the Garrison, the soldiers will leave the fortress permanently and no one will remain to defend the Border Castle. On $20^{\text {th }}$ of April, John Kovács, the Cavalry Lieutenant, started out toward Sárospatak in order to offer his service for Sophia Báthory and get steady payout from her. There were some persons among John Kovács's attendants whose comrades and compeers planned to leave the Fortress at Saint George's Day and try to seek some well-paying jobs. ${ }^{21}$

On the beginning of May, Martin Unger wrote to Koháry that the border soldiers had not got their payout yet. For that reason, he permitted on $1^{\text {st }}$ of May that a Hungarian-German group of 80 from Fil'akovo to meet the Muster-master so as to ease their excitement deriving from impatience, and, on the second hand, convoy him back to the fortress. The Deputy-Captain expressed their hope that they would reach Divín that day, and return to Fil'akovo as far as they could.

Koháry was also informed of the fact from Unger's letter that Novohrad County wanted to recruit foot-soldiers, and Halič was announced as the place of the recruitment. A monthly payout of 10 forints would be promised to the non-commissioned officers, which roused several border soldiers' interest from Fil'akovo. Martin Unger just asked them if they could wait for a week at least, until Koháry's response concerning the payout will arrive. ${ }^{22} \mathrm{He}$ obviously wrote another letter between $7^{\text {th }}$ and $13^{\text {th }}$ of May, in which he might mention the soldiers' payout, because Koháry replied him all in all on $14^{\text {th }}$ of May, that he would endeavour to obtain the payouts from state sources, and not for the registered border soldiers only, but also for the newly recruited foot-soldiers. The Commander-in-Chief and General-Captain of Fil'akovo did not discourage that certain soldiers led by Benedict Detky enlisted to the troops of the

\footnotetext{
${ }^{20}$ MNL-OL $40575^{\text {th }}$ roll № 803, (ŠABB, Archive of the Koháry Family, Pars I.), Martin Unger's letter to Stephen Koháry (Fil'akovo, $21^{\text {st }}$ of April, 1664).

${ }_{21}$ MNL-OL 40574th roll № 273, (ك̌ABB, Archive of the Koháry Family, Pars I.), Francis Újlaky's letter to Stephen Koháry (Fil'akovo, $21^{\text {st }}$ of April, 1664).

${ }^{22}$ MNL-OL C 1297th roll № 15932, (ŠABB, Archive of the Koháry Family, Pars V.), Martin Unger's letter to Stephen Koháry (Fil'akovo, $5^{\text {th }}$ of May, 1664).
} 
The problems of the military provisions and payouts and their consequences ...

County, because they stayed together at least. But he did not resent that the Cavalry Lieutenant John Oláh absented without leave for a certain reason. Koháry hoped himself that he would get an absent with leave and return to home: "...Maybe I am back to home for a few days...because I am fed up with this unpaid service of me and the usual problems and annoyance with the damned roaming folk..."23

In February Koháry already started gathering and purchasing of the wheat as essential bread crops. By order of him, Military Judge Stephen Oroszlány, accompanied with few soldiers, had gone to Rimavská Sobota, where he had forced the inhabitants into unfolding the pits used by them for winter storage of the wheat, and used a forced buying-up at a fixed price. Firstly, those pits had been unfolded which were owned by richer persons and not residing in the country-town, for example the pits of Martin Varga from Šavol'. Everybody in the surroundings knew that he has further four pits of wheat on his dwelling, which he would aim for exclusively merchandizing. The wheat had been taken out of the storage pit, measured and weighed 32 "kilas" (equals to 1,600 kilograms), and had been immediately conveyed to Fil'akovo. The Military Judge had taken it at no expense, because, in his opinion, the owner was too wealthy to be disprofited by reason of the taken wheat. Another five pits had been also begun to unfold, four of them owned by dwellers of Rimavská Sobota, and one of them had belonged to a man residing in Ožd'any. He had bought up the whole wheat taken out of the storage pits by the condition of Koháry's order: the owner had been supposed to sell two "kilas" per every ten "kilas". But Stephen Oroszlány had come up against difficulties: one of them had been the inhabitants' exasperation, namely, they had cast reproaches upon him during the unfolding of the storage pits, and not only the women had burst into tears, but also unusually the men, and he had been blamed for taking the last bit of bread out of their mouth. They had complained that almost all of them bought the wheat expensively, so they would be awfully disadvantaged by reason of the forced buying-up. But Oroszlány had not care for the complaints, he had continued his task, though he had been afraid that a proTurkish traitor shall informed the Ottoman Garrison of Eger about the crops, and a hostile unit would make a dash at Rimavská Sobota, and he would be captured and the wheat also preyed by the Turks. On the second hand, the efforts of the Military Judge had been balked by the fact that he had explored less storage pits than expected. He had made the whole market square dig up, but he had found only empty storage pits.

${ }^{23}$ MNL-OL C 777th roll № 2154, (ŠABB, Archive of the Koháry Family, Pars IV.), Stephen Koháry's letter to Martin Unger (Pukanec, $14^{\text {th }}$ of May, 1664). 
Some owner had got dope information about Oroszlány's intention, and had carried his wheat away so as to hide it away somewhere. For example, two men named Dorogfy and Ivócs, in addition, Nicholas, the Scribe, had taken the content of 4-5 storage pits away. John Papis and Gregory Papis had also conveyed their wheat out of the pits, but it had been licensed by Martin Unger, Deputy-Captain of Fil'akovo. ${ }^{24}$

The afore-mentioned crops provided only the necessity of Filakovo. In general, there was a shortage of food throughout Lower Hungary. In the beginning of April, General Louis de Souches encamped near Trenčín with the Imperial troops, and wrote to Francis Wesselényi that there was almost none kind of food for his soldiers, and he and the commissariat officers needed to use their every effort to procure only a mouthful (!) of bread for the troops. ${ }^{25} \mathrm{Few}$ days later, for the matter of the quickening of the conveyance of the provisions, the General nearly begged to the Palatine that he immediately would send Michael Bory to the camp for the negotiating, even if it would be at night. ${ }^{26}$

The serious shortage of food also lasted during and after the operations against Nitra Fortress. At the time of the Siege of Nitra, Louis de Souches asked the Palatine to pass every food provision surrendered by the counties without any hesitation to the obsidional army. ${ }^{27}$ In his letter dated from $21^{\text {st }}$ of April, Francis Wesselényi enclosed an order elaborated for sending to the counties. When it was come to the General's hand, he immediately wrote to several counties. He also wrote a letter to Novohrad County, in which he urged for not only the general insurrection, but also the conveyance of all kind of food, and menaced it that in case of its negligence, measures exerted by military execution would be directed against the County. ${ }^{28}$ Then the General acknowledged in his letter to the Palatine,

\footnotetext{
${ }^{24}$ MNL-OL C 1294th roll № 15359, (ŠABB, Archive of the Koháry Family, Pars V.), Stephen Oroszlány's letter to Stephen Koháry (Rimavská Sobota, $13^{\text {th }}$ of February, 1664).

25 MNL-OL E 199, $6^{\text {th }}$ box, 25 th pallium, fol. 2-3, Archivum familiæ Wesselényi (1583-1732), General Louis de Souches's letter to Francis Wesselényi (Trenčín, $5^{\text {th }}$ of April, 1664): ,...maximam video difficultatem, nam, sicut ante horam scripsi, nulla hic est facta provisio et ego sicut minimus Commissariorum annonæ allaborare debeo in procurando frustolo panis pro milite...". ${ }^{26}$ In the same place, fol. 4-5, General Louis de Souches's letter to Francis Wesselényi (Bojnice, $10^{\text {th }}$ of April, 1664).

${ }^{27}$ In the same place, fol. 6, General Louis de Souches's letter to Francis Wesselényi (Imperial Camp by Nitra, $16^{\text {th }}$ of April, 1664).

${ }^{28}$ National Archives of Hungary - Archive of Nógrád County Salgótarján, IV-1/b, Nógrád vármegye közgyúlési iratai, $1^{\text {st }}$ box, 1664/11, Documents of General Assembly of Novohrad County, General Louis de Souches's letter to the Magistrate of Novohrad County (Imperial Camp by Nitra, 24 ${ }^{\text {th }}$ of April, 1664): ,...Hinc est, quod Easdem Domines Vestras harum serie requirendas duxerim, quatenus Exercitui mihi concredito non modo annonamaliaque Victualia pro parata pecunia, verum etiam gratis in Campum convehere velint, secus militibus excurrendi venia concedi debebit nec onera aut belli pressura evitari poterunt, ad majorem vero hostis Confusionem velint quoque in persona armati huc confluere...".
} 
The problems of the military provisions and payouts and their consequences ...

written in the following day, that, in fact, he did not believe in neither the conveyance of the food supply, nor the effectiveness of the general insurrection of the counties. ${ }^{29}$ Few days later, he reported to the Palatine that the couriers had brought such information of those orders from varied places, which almost compelled the inhabitants for desolation (such as the order of the Commissariat Officer of Fil'akovo Border Castle). The General let the Palatine know that he would not detain the carts and beasts of draught sent by the counties, moreover, he gave the coachmen travelling warrant for the overtrick route, taking care of the more quickening of the conveyance of the food supplies for the obsidional army in such way. ${ }^{30}$

Michael Bory deemed the situation of the lacking of food so: "...Though General de Souches should not launch the operations from Nitra, because there cannot be found any wheat in the storage pits right up to Fil'akovo and other further eastern places, unless he would not collect all of it in one place..." 31

Martin Unger came forward with a suggestion for the relieving of the Hungarian army's lack of food supply. He had been informed by his intelligence agents that the Turks were about to gather and dispatch carts loaded with food from Eger and other Turkish garrisons, situated eastward from Buda, so as to replenish the food supply of Nové Zámky and get ready for a longer siege. Although this cargo would be escorted and protected by Janissaries and mounted units, but if spies would be sent from the Hungarian camp for exploring their route, it would be very easy to raid them with a stronger military unit on the occasion of a night resting, and all of carts would be taken by surprise. ${ }^{32}$

In the middle of May, due to the very shortage of the food, Stephen Koháry was to move the Hungarian troops near Vel'ké Uherce "...so as not to consume either the fodder or the food supplies of the United Army...". The Imperial War Council thought that the Hungarians would easily find food, wheat and fodder there and simultaneously attend to the defence of that territory. ${ }^{33}$

\footnotetext{
${ }^{29}$ MNL-OL E 199, $6^{\text {th }}$ box, $25^{\text {th }}$ pallium, fol. 7-8, Archivum familiæ Wesselényi (1583-1732), General Louis de Souches's letter to Francis Wesselényi (Imperial Camp by Nitra, $25^{\text {th }}$ of April, 1664).

${ }^{30}$ In the same place, fol. 9-10, General Louis de Souches's letter to Francis Wesselényi (Imperial Camp by Nitra, 29th of April, 1664).

${ }^{31}$ MNL-OL E $199,4^{\text {th }}$ box, $16^{\text {th }}$ pallium, fol. 6-7, Archivum familiæ Wesselényi (1583-1732), Michael Bory's letter to Francis Wesselényi (Banská Bystrica, $1^{\text {st }}$ of May, 1664).

32 MNL-OL 40575 th roll № 803, (ŠABB, Archive of the Koháry Family, Pars I.), Martin Unger's letter to Stephen Koháry (Fil'akovo, 21 $1^{\text {st }}$ of April, 1664).

${ }^{3}$ MNL-OL E 199, $4^{\text {th }}$ box, 61 ${ }^{\text {st }}$ pallium, fol. 11-12, Archivum familiæ Wesselényi (1583-1732), Stephen Koháry's letter to Francis Wesselényi (Žiar nad Hronom, 22 nd of May, 1664).
} 
An Imperial Army of 5,000 soldiers under the command of General Gottfried von Heister arrived in North-Western Hungary. It should be available either in the Transdanubian Region or in Northern Hungary, depending on the military situations. Finally, these troops were directed to the Army of Louis de Souches as reinforcements, but due to the incomplete arrangements, it was stagnated near Trnava between $20^{\text {th }}$ and $23^{\text {rd }}$ of May, without any command, moreover, without any food, either purchased or assigned for free. ${ }^{34}$

The lack of provision also had a great effect on the military operations in the very of May. On 31 $31^{\text {st }}$ of May, Michael Bory arrived in Žiar nad Hronom, where he negotiated with General Louis de Souches in a very serious matter. Namely, the Imperial leader wanted Bory to inform the Palatine that he would dispatch the troops toward Hronský Beňadik on $2^{\text {nd }}$ of June by all means, but after the reaching that place, the army would turn wherever the food supply would be available, or would stay there while the food would be arrived, and in that case, the General would be accommodated to the Palatine's plans. Besides, Bory gladly informed the Palatine that 400 „fertály" of wheat [approximately equals to 10,000 kilograms] would be arrived from Vígl'aš to Žiar nad Hronom on $1^{\text {st }}$ of June. But he asked Wesselényi to exercise an influence upon Adam Forgách that he would order the Deputy-Lieutenant of Zvolen County to load more 100 „fertály" of wheat [approximately 2,500 kilograms] onto the carts, and so it would be a proper quantity for the soldiers' alimentation. ${ }^{35}$

General Louis de Souches marked that the conveyance of the food supply had been really started on $1^{\text {st }}$ of June ${ }^{36}$, then on the following day, he notified Wesselényi that he would be tend to accept his directions and plans concerning with the marching of the army. But he asked the Palatine to send Michael Bory to him as far as possible, who had promised that he gained 2,000 "mérő" of wheat [approximately equals to 100,000 kilograms). If that does not arrive to the camp in a little while, the operations would be easily failed. ${ }^{37}$

By the order of Francis Wesselényi, the settlements and the economic units were obliged to surrender certain quantity of wheat crops.

\footnotetext{
${ }^{34}$ MNL-OL E $199,5^{\text {th }}$ box, $65^{\text {th }}$ pallium, fol. 166-167, Archivum familiæ Wesselényi (15831732), George Lippay's letter to Francis Wesselényi (Bratislava, 20 $0^{\text {th }}$ of May, 1664) and in the same place: fol. 162-163, George Lippay's letter to Francis Wesselényi (Bratislava, $23^{\text {th }}$ of May, 1664).

${ }^{35}$ MNL-OL E 199, $4^{\text {th }}$ box, $16^{\text {th }}$ pallium, fol. 8-9, Archivum familiæ Wesselényi (1583-1732), Michael Bory's letter to Francis Wesselényi (Žiar nad Hronom, 31 ${ }^{\text {st }}$ of May, 1664).

${ }^{36}$ MNL-OL E $199,6^{\text {th }}$ box, $2^{\text {th }}$ pallium, fol. 15-16, Archivum familiæ Wesselényi (1583-1732), General Louis de Souches' letter to Francis Wesselényi (Žiar nad Hronom, $1^{\text {st }}$ of June, 1664).

37 In the same place, fol. 17-18, General Louis de Souches' letter to to Francis Wesselényi (Žiar nad Hronom, $2^{\text {nd }}$ of June, 1664).
} 
The problems of the military provisions and payouts and their consequences ...

The Palatine gave Leslie Keresztúry charge over the collecting of the wheat near Bojnice. His task was not only the collecting of the wheat, but also the gaining of the carts and draught-animals. Keresztúry went to that place with the military assistance of Captain Stephen Szobonya and his soldiers (as signed in the Palatine's order) and considered the possibilities. The commissioner nobleman soon reported Wesselényi that enough quantity of wheat crops were available in the area, but problems might occurred with the conveyance. "...There is a difficulty here, because nobody wants to be a coachman. Our threats or requests were totally in vain, the assembled peasants pronounced with extremely intention that none of them undertake the task. To solve this problem, Mylord, weapons must be used, not only simple forcing..." But the soldiers' armed threating angered the peasants - Keresztúry added to his report to the Palatine. The mentioned bondsmen were subjects of George Lippay, Archbishop of Esztergom, and George Szelepcsényi, Bishop of Nitra and Chancellor of the Hungarian Court Chancellery. One of them, Lippay who simultaneously was also Royal Chancellor ${ }^{38}$, wrote an expostulative letter to Keresztúry, in which pronounced that he would not tolerate any military execution, and, if it occurs, he would immediately report to the Sovereign. But in that case if Wesselényi and Leopold the First would issue such a mandate in which they order all kind of noblemen (magnates, gentries and the owners of the alm-lands) to surrender the food and other crops (even if it would be carried out by forcing) for the sake of the defence and keeping of the Home and the Country, George Lippay immediately comply with it, and order his subjects to give the wheat and the carts over. ${ }^{39}$

Keresztúry proudly informed the Palatine in his following letter dated from $8^{\text {th }}$ of June that he had managed to gain enough quantity of wheat at no expense for the army, and, for comparison, mentioned that the current market-price of one "mérö" of wheat in Bratislava (approximately equals to 50 kilograms) was five and a half forints. We can extrapolate from Keresztúry's letter that some carts were sent from the Imperial Camp near Levice to Bojnice so as to be loaded with a small portion of wheat. Leslie Keresztúry, Michael Bory and the German commissariat officers endeavoured to carry the tasks out, but due to the ample rainfalls (which caused spates not only along the Nitra River, but also by smaller

\footnotetext{
${ }^{38}$ Leslie Keresztúry mentioned „Sir Chancellor” in his letter, but we cannot extrapolate from that whether it is related to George Szelepcsényi, Hungarian Court Chancellor (http://lexikon.katolikus.hu/S/Szelepcs\%C3\%A9nyi.html [1 ${ }^{\text {st }}$ of June, 2016]), or George Lippay, Royal Chancellor. But on the base of the archival sources, George Szelepcsényi is excludable, because he stayed in Regensburg (Ratisbona) in May 1664, and in Krakow in June 1664 . - MNL-OL E $199,6^{\text {th }}$ box, $5^{\text {th }}$ sheaf, $101^{\text {st }}$ pallium.

${ }^{39}$ MNL-OL E $199,4^{\text {th }}$ box, $60^{\text {th }}$ pallium, fol. 1-2, Archivum familiæ Wesselényi (1583-1732), Leslie Keresztúry's letter to Francis Wesselényi (Bojnice, $3^{\text {rd }}$ of June, 1664).
} 
creeks) they partly fulfilled those. Meanwhile, the escorting German musketeers begun to grumbling on $7^{\text {th }}$ of June, and wanted to return to the camp with their unloaded carts. Then Michael Bory agreed with them to set off with the loaded carts and left the unloaded ones in Bojnice, which would be also loaded by the bondsmen on $8^{\text {th }}$ of June, and would be conveyed under the personal presence of him to the camp. (In Keresztúry's opinion, it was an ingenious agreement, because the soldiers would return with the loaded and unloaded carts at the same time, it would be concluded by the whole camping army that there was no food and it would be demoralizing for them.) Keresztúry also wrote to the Palatine, that the further food conveyance would really need for the inhabitants' carts, but it would be solved by military forcing, so he forwarded the Palatine's mandate concerning about it to Captain Stephen Szobonya. ${ }^{40}$

On the $9^{\text {th }}$ of June, 80 cartloads of wheat were conveyed to Žiar nad Hronom, and he would expect further 125 or 150 carts by $10^{\text {th }}$ or $11^{\text {th }}$ of June - wrote Michael Bory to the Palatine, moreover, he added that the Land Stewarts of Hlohovec and Šintava promised grain crops conveying to Nitra. (But Bory sadly needed to report to the Palatine that certain commissioned persons began to merchandize with the wheat as it was reached to him, and not forwarded to the army.) ${ }^{41}$ Bory immediately set off with the above mentioned loaded carts toward the Camp near Levice, and wrote a letter from Hronský Beňadik to Stephen Koháry so as he was not worried about the food. ${ }^{42}$

Another commissioned person of the Palatine, Johann Albert OritzKoletzky, was charged over the collecting of the wheat crops in Banská Bystrica and the surroundings. He reported that he could not gain more wheat in Slovenská L'upča, but the crops taken from the local parish priest had generated temporary offense which was growingly manifested. The inhabitants of Banská Bystrica already became aware of that he had collected and stored the wheat in the Maschowski House. But he learnt that he was accused of by some of the inhabitants before the Palatine that he had robbed the grain crops reserved for their home needs. He asked the Palatine not to give credit to that reports, because those were originated from such persons who refused themselves him to have a look at their stocks, and take an inventory of the grains, and draw them into buying.

\footnotetext{
${ }^{40}$ In the same place, fol. 3-4, Leslie Keresztúry's letter to Francis Wesselényi (Bojnice, $8^{\text {th }}$ of June, 1664).

41 MNL-OL E $199,4^{\text {th }}$ box, $16^{\text {th }}$ pallium, fol. 10-11, Archivum familiæ Wesselényi (15831732), Michael Bory's letter to Francis Wesselényi (Žiar nad Hronom, $10^{\text {th }}$ of June, 1664). 42 MNL-OL C 1297th roll, № 15936, (ŠABB, Archive of the Koháry Family, Pars V.), Michael Bory's letter to Stephen Koháry (Hronský Beňadik, $10^{\text {th }}$ of June, 1664).
} 
The problems of the military provisions and payouts and their consequences ...

Oritz-Koletzky reported the fulfilling of his task to the Palatine so: a deputation of the inhabitants of Banská Bystrica had come to him not long ago, and he had complied with their requests, but he was afraid of causing himself lot of problems concerned with his task. As he had collected far less grain crops as it would be needed: he had not taken the rest of wheat of a man named Gyürky; by the intervention of Michael Libercsey, he had collected only 10 "méro" of wheat (approximately equals to 500 kilograms) from the compulsory 80 "méro"", and had only accepted 15 "mérő" from the quantity of the 100 "mérö" imposed by Michael Bory on the town. Later Michael Libercsey had looked him up, and had offered further 5 "méro"" of wheat which would be sent over from Krupina, and, if it would be possible, his son would send a little more of them as victualage. Oritz-Koletzky had accepted this agreement, because Libercsey had promised that only one "méro" of wheat would not be merchandised by him at all. But he had been fraudulent, because he had made his son bring up 3 cartloads of wheat from Krupina, who had begun to trade with it in Radvaň. ${ }^{43}$ Before Oritz-Koletzky had been informed about it, and had got there, the young man had sold almost all, except for 12 "mérő". As the commissioned person had laid claim to the earlier promised 5 "mérő" of wheat, he could purchase that 30 "mérő" of grain crops agreed by the inhabitants of Banská Bystrica for 60 forints. This sum had been handed over by him to Paul Némethy, who had given a receipt of payment about it. Oritz-Koletzky wanted to convey all the wheat and other kind of foods to Žiar nad Hronom by $10^{\text {th }}$ of June. ${ }^{44}$

After having been received Francis Wesselényi's mandate dated from $7^{\text {th }}$ of June, Johann Andreas Joanelli, Count of Mining Chamber in Banská Štiavnica, began to collect a certain amount of wheat from the free royal town. He had called John Bartakovics, Deputy-Lieutenant of Hont County, and admonished him to hand over that wheat imposed on him, as he was recently possessing more than 40 "mérő" of flour [2,000 kilograms] and 30 "köböl" of wheat [3,000 kilograms], and he had collected earlier 40 "mérő" of grain crops from other inhabitants. Joanelli had to know just when, that certain dwellers possessing land properties had locked up 70 "mérő" of grain crops in secret on a certain place. But when Joanelli wanted to see this store, the reply was that the key of the house had been disappeared and could not be found. Then the Chamber President took the all quantity of wheat and flour from Bartakovics, the other collected grain crops also gained, and stashed all of them into the Castle

\footnotetext{
${ }^{43}$ Nowadays, the contemporary settlement is a quarter of Banská Bystrica.

${ }^{44}$ MNL-OL E 199, $5^{\text {th }}$ box, $78^{\text {th }}$ pallium, fol. 1-2, Archivum familiæ Wesselényi (1583-1732), Johann Albert Oritz-Koletzky's letter to Francis Wesselényi (Banská Bystrica, $9^{\text {th }}$ of June, 1664).
} 
of Banská Štiavnica. Joanelli offered a bargain to Bartakovics: if the key of that house in which the 70 "méro" of wheat was hidden by the inhabitants would be found within two days, the Deputy-Lieutenant would retain 20 „méro"” of wheat for his home needs.

Joanelli reported to Wesselényi that he could collect and transport to the Camp near Levice only 20 large earthenware jar of grain crops from the required 300 "mérő", because there was no more to be gained from other places except Banská Štiavnica. But from that it was to be retained 40 „méro"” for the Palatine's family and the promised 20 „mérő" for John Bartakovics, unless Wesselényi would not order other else. Thus, it remained 100 „mérő" of food consisted of wheat and flour, which had already been conveyed from Banská Štiavnica by him.

Joanelli also informed the Palatine that General Louis de Souches highly complained about the dire lack of bread, and he was afraid of the dragging of the siege and he would not able to solve the food supply of the Imperial Army. ${ }^{45}$

On $13^{\text {th }}$ of June, John Rottal and Paul Vice conveyed several cartloads of wheat from Ilava toward Bojnice. They set off early morning, and they thought that they would reach the destination place at 4 o'clock afternoon, but due to the floods, they compelled to stop in a village named Dobrosznia [unidentified settlement by me] at 3 o'clock. They planned that they would wait for arriving of the carts left behind them in the evening, and they would continue their way on the following day to Bojnice. But the problems were multiplied, because shepherd-looking, suspicious persons were aggregating around the carts, and they drew to furthermore only when the escorting musketeers captured some of them. ${ }^{46}$

It occurred that the commissioned food collectors took more than the required quantity. George Berényi went to Nitra Fortress and promised to give 1000 "szapu” of wheat (approximately equals to 100,000 kilograms) for supplying the army. But as he returned to home at the evening, he was astonished to see that the soldiers had loaded up 60 carts more than the offered quantity, as they had high-handedly added that wheat, which was put away by him for the sowing of the following year, so they imperilled his family's living for three years at least. ${ }^{47} \mathrm{~A}$ member of the Count Csáky Family indignantly complained to Joanelli, because

\footnotetext{
45 MNL-OL E 199, $4^{\text {th }}$ box, 49 $9^{\text {th }}$ pallium, fol. 1-2, Archivum familiæ Wesselényi (1583-1732), Johann Andreas Joanelli's letter to Francis Wesselényi (Imperial Camp by Levice, $10^{\text {th }}$ of June, 1664).

${ }^{46}$ MNL-OL E $199,7^{\text {th }}$ box, III. item, $2^{\text {nd }}$ pallium, fol. 32-33, Archivum familiæ Wesselényi (1583-1732), John Rottal's letter to Francis Wesselényi (unreadable place, $13^{\text {th }}$ of June, 1664).

47 MNL-OL C $770^{\text {th }}$ roll № 1148, (ŠABB, Archive of the Koháry Family, Pars IV.), George Berényi's letter to Stephen Koháry (Dolné Obdokovce, $10^{\text {th }}$ of June, 1664).
} 
The problems of the military provisions and payouts and their consequences ...

Joanelli had confiscated 25 „mérő" of wheat and flour from him, and left only 10 "méro"” for his family, what he considered as act of plundering. ${ }^{48}$

The Palatine made an attempt of purchasing those demesnes, which were the part of the territory of military operations. Wesselényi wrote a letter to Archbishop George Lippay on $15^{\text {th }}$ of May from Banská Bystrica, in which he offered that he would purchase en bloc the grain crops from the paupers and draft-horses of the alms-land of Žiar nad Hronom, because there was no possibility to gain other demesnes for feeding the army. The Archbishop replied that the demesne was very small and almost perished at that time, so it was unfit for purchasing. ${ }^{49}$

Francis Wesselényi also tried to apply the chamber incomes for covering the military expenses. In one of his letter dated in the middle of May and sent from Banská Bystrica, he asked Stephen Zichy, the President of the Hungarian Chamber, if he would give 4,000 Thalers from the toll incomes of the thirtieth custom-house (in Hungarian: harmincadvámhely, in Latin: tricesimalium officium) of Žilina for the military expenses. In his reply, Zichy wrote that only an infinitesimal sum of money has come in to the Treasure of the Hungarian Chamber in the year of 1664. The available money was to be for the maintenance of the relay stations and for covering the payouts of the castle servants. The Counties were not able to pay the Crown Tax to the Treasure of the Chamber at all. The Imperial Armies impounded all kind of incomes from Trenčín to Croatia, so the thirtieth custom-houses of that territories did not also forward money to the Chamber. The office clerks had quitted their work because of the lack of their salary, moreover, Zichy also complained to the Palatine: "...All of my demesnes are now perished, behold, I am falling on evil days with my children!...", as he also had not any salary for a long while. But he promised to order the customcollector of the thirtieth custom-house of Žilina so as to scrape together 2,000 forints somehow, and would send to him. Stephen Zichy also implied the poor condition of the Bratislava area. He was compelled to beg for only a simple saddle-horse from the Palatine, because all the horses were impounded for military purposes in the surroundings, so there was no horse to buy even for cash at all. Zichy thought so, that the Chamber of Spiš might have some ready money, because military operations had not recently launched on that area. Thus, Zichy promised to send an order to Košice, that the Chamber would immediately forward the Palatine Tax to him. ${ }^{50}$

\footnotetext{
${ }^{48}$ MNL-OL E 199, $4^{\text {th }}$ box, 49 $9^{\text {th }}$ pallium, fol. 1-2, Archivum familiæ Wesselényi (1583-1732), Johann Andreas Joanelli's letter to Francis Wesselényi (Imperial Camp by Levice, $10^{\text {th }}$ of June, 1664). ${ }^{49}$ MNL-OL E $199,5^{\text {th }}$ box, $65^{\text {th }}$ pallium, fol. 162-163, Archivum familiæ Wesselényi (1583-1732), George Lippay's letter to Francis Wesselényi (Bratislava, 23 ${ }^{\text {rd }}$ of May, 1664).

${ }^{50}$ MNL-OL E 199, $6^{\text {th }}$ box, $124^{\text {th }}$ pallium, fol. 7-8, Archivum familiæ Wesselényi (1583-1732), Stephen Zichy's letter to Francis Wesselényi (Bratislava, 22 $2^{\text {nd }}$ of May, 1664).
} 
The lack of food (combined with the threat of the Turks) conduced to the fleeing of the plebeian dwellers of Nitra. By the beginning of July, extremely big Ottoman army was aggregated to re-capture Nitra and Levice, and the inhabitants of Nitra were directly endangered. The richer persons managed to move to countryside, but the poorest and non-propertied ones stayed there, because they hoped to be provided in some degree by the Magistrate. But they did not get any food, and they were exposed to the Turkish danger, too. Stephen Koháry gave an oral order to either the Hungarian military leaders or the Imperial Colonel of the Garrison: if they would not supply the poor dwellers, he would let them go outside the walls at least. The competent persons did not take into consideration that order, and demanded in written form to let the poor people go out of the town. The plebeians of Nitra immediately sent a delegate to the Hungarian leader, writing this: "...For the sake of God, we are asking Your Eminency, please, You write a letter to the Hungarian and German commanders that they will emit us freely, so as all of us can find a temporary place to linger in together with our tiny values. It may take only a week and being seen my destiny, because the Turkish dogs totally wait for the hour of reckoning with us..." 51

\section{The lack of the proper supplying causes abuses}

Thus, the encamped troops did not get regularly their payouts, and despite the fact that the Counties arranged their food supply, the soldiers committed abuses in such a large measure, that Stephen Koháry had to pay attention to them. He charged civil persons with a task to pick up information about the destiny of the stolen grain crops and other foods. John Horváth, living in Nitrianska Streda, was one of them. He reported to Koháry that he had been informed by certain bondsmen that the stolen food and wheat had been conveyed toward Jelenec Castle by such soldiers and heyducks, who lived beyond the camp. But he could not answer the question, whether the food would be really delivered to Jelenec, or being remained in the villages? John Horváth also reported, that certain dwellers from Sl'ažany and Illatnya [unidentified settlement] pretended to be heyduck servants from Jelenec, and when they demanded food from dwellers of other villages, they took it because of giving credit to them. Horváth also informed his constituter that it was hard to extract the destination of the conveyance or other information from the heyduck servants and armed soldiers, because if the bondsmen asked them whatever, or went too close to them, they immediately became dismissive and morose. ${ }^{52}$

\footnotetext{
${ }^{51}$ MNL-OL 40574 $4^{\text {th }}$ roll № 443, (ŠABB, Archive of the Koháry Family, Pars I.), the letter of the plebeian dwellers of Nitra to Stephen Koháry (Nitra, $9^{\text {th }}$ of July, 1664).

52 MNL-OL C 1297th roll № 15933, (ŠABB, Archive of the Koháry Family, Pars V.), John Horváth's letter to Stephen Koháry (Nitrianska Streda, $1^{\text {st }}$ of May, 1664).
} 
The problems of the military provisions and payouts and their consequences ...

Stephen Koháry also waited reports from the dwellers, village mayors and the landlords of the surrounding settlements about the abuses of the cattle-lifter soldiers: he took great interest in the circumstances of the crime, the estimation of the damages, and tried to begin to arrange the retrieval or satisfaction. For example, he wrote from the camp by Nitra to John Ebeczky, asking him whether a certain Peter Róka really had driven off cattle from Vráble, and had tried to purchase in Zvolen? Ebeczky answered him that the mentioned soldier had driven off the cattle to the mining town Banská Štiavnica, so they could be found them there. ${ }^{53}$

At the end of June, Sigismund Csáky was the temporary General-Captain of the recaptured Levice. In his letters written to Koháry, we can find several data about the encamping soldiers' abuses. Among other occasions, once thieving persons had taken 35 cattle and 12 horses from behind the plough near his four villages: Vámosmikola, Perovčany, Bielovce and Ipel'ský Sokolec. Moreover, "two young rascally lads of them" sideward shot at one of Paul Csáky's land stewart. (Paul Csáky was the commissioned General-Captain of Levice, but he was absented with leave and stayed in North-eastern Hungary at that time.) But he was not harmed, and went closer to them so as to see them for the later identifying, and then one of the cattle-lifters strongly slapped him on the back. ${ }^{44}$ The aggrieved inhabitants of the villages followed the cattle-lifters, and caught them up by the vineyards of Balážske Ďarmoty, when they immediately tried to compound about the repurchase of the livestock. The cattle-lifters demand 2 Thalers per cattle at the first day, but one day later the price was doubled by them. The bondsmen were not able to pay that sum, so they returned to home and appealed to his landlord, Sigismund Csáky. They told him that the gang consisted of 15 men: seven of them were bondsmen from the Csáky estates who drove the livestock from their own village out of revenge. And eight of them were such soldiers who were „...just straying, and not serving continuously under none of banner...", but the bondsmen did not know their names. Right now Csáky sent mounted soldiers to chase the thieves who set off toward Banská Štiavnica with the booty, but as they caught sight of the Csáky soldiers near Demandice, immediately let loose the stolen livestock, and fled. ${ }^{55}$

In the case of more serious injuries caused by the encamped soldiers in his estates, Sigismund Csáky mounted a horse himself. For example,

\footnotetext{
${ }^{53}$ In the same place, № 15934, John Ebeczky's letter to Stephen Koháry (Zvolen, $13^{\text {th }}$ of May, 1664).

${ }^{54}$ MNL-OL C $1276^{\text {th }}$ roll № 12605 , (ŠABB, Archive of the Koháry Family, Pars V.), Sigismund Csáky's letter to Stephen Koháry (Levice, $26^{\text {th }}$ of June, 1664).

55 In the same place, № 12700 , Sigismund Csáky’s letter to Stephen Koháry (Levice, $28^{\text {th }}$ of June, 1664).
} 
on $26^{\text {th }}$ of June, he was compelled to ride out with 30 mounted soldiers and a group of Hungarian-German infantrymen, because he was informed that border soldiers belonging to Krupina Fortress had stolen all the cattle of Lišov, and they had headed for the Cat Ferry of Hron River. The cattle-lifters had ferried through the river with the animals, so Csáky left the infantry unit by the ferry place, and chased the thieves with his mounted soldiers, and run them down by the meadow of Kozárovce. The thieves began to curse them and rattle their armaments threateningly, so Csáky and his soldiers left them behind and went to the Hungarian Camp so as the Count personally complained the theft to Stephen Koháry. Meanwhile the cattle-lifters shot at some soldiers of Csáky, took three horses from two of them and did not want to give back at all. The gang of the thieves aggregated 50 mounted soldiers, and some of them were recognized by Csáky. The thieves were continuously shouting and swearing on that "the General" (= Louis de Souches) had given licence for them to driving the cattle off. But Koháry just did not stay in the camp, and Csáky turned back, as he left his infantry unit by the Cat Ferry. This infantry unit was belonged to the Garrison of Levice, so he had to bring it back to the Fortress as far as he could. But Csáky asked Koháry to bring the encamped soldiers under discipline, even to threaten them, that every malefactor will carry heavy aftermaths. Thus the similar cases would not occur. ${ }^{56}$

But the abuses of the encamped soldiers did not cease around Levice. Sigismund Csáky wrote to Stephen Koháry three times in the end of June, moreover, once he sent a man to the Commander so as to await his decision concerning the border soldiers of Balážske Ďarmoty and Drégelypalánk, who had taken three horses with stable gears by force from soldiers of Levice and were behindhand in giving back them to the original owners. Simultaneously, he informed Koháry, that the German musketeers of Levice took captive six Hungarian soldiers from the camp, by who 40 such cattle were found which were not owned by them. Csáky instantly ordered their detention. ${ }^{57}$

In the close surrounding of Nitra was situated Bodok ${ }^{58}$ settlement, and from its landlord, from George Berényi, the Hungarian soldiers encamped by Hlohovec stole all the cattle by cunning. They made a dash at the settlement at dawn, constantly shouting „Allah”. As the villagers thought they were really Turks, they defended their house and own family, and did not

\footnotetext{
${ }^{56}$ In the same place, № 12600 , Sigismund Csáky's letter to Stephen Koháry (Levice, $26^{\text {th }}$ of June, 1664).

${ }^{57}$ In the same place, № 12696, Sigismund Csáky’s letter to Stephen Koháry (Levice, $1^{\text {st }}$ of July, 1664).

${ }^{58}$ Nowadays Dolné Obdokovce (Alsóbodok).
} 
The problems of the military provisions and payouts and their consequences ...

take care of the living stock, so the thieves easily drove the cattle off. Berényi was disgusted with the theft, as any cattle did not remain for plowing due to the cattle-lifting, and wrote that sarcastic words: „...The Good Braves should not complain at all, that they should have no payouts, because some of them gain money enough for a year with cattle-lifting just since the camp has been situated near Hlohovec!..." 59

Whole county might suffer from the military abuses. Archbishop George Lippay, at that time Lord-Lieutenant of Bratislava County, complained for the suffering of the inhabitants. The inhabitants of the County lingered in toward the White Mountains, where they felt safer. Stupava was completely burnt by the raiding soldiers, its dwellers fled. The Archbishop wrote that text about the behaviour of the soldiers and the complaints of the civil inhabitants: „... These miserable persons are totally suffered by the Hungarian soldiers. It is awfully and flagrant that they do. Nowadays, when I sent a Jesuit with my letter toward Košice, this monk was attacked and killed by them. Due to the abuses, no one could plow and sown, no one could step inside out of his house. The soldiers at their own pleasure choose a house, billeting themselves there, and forced the dwellers to give them anything what they want, so the poor people are being completely ransacked. Recently, few hundreds of soldiers being under the banner of Count Francis Nádasdy have billeted in the Žitný ostrov without no information, and the whole territory have been divided among the unit so as the settlements how many victuals and supplies was obliged to give them. Besides, the poor people's misery and poverty is grown so high that the County Magistrate has been compelled to threat the soldiers, that they will not give up the exploitation of the inhabitants, general insurrection will be called together, and would expulse them out of the County; and I have suggested myself this, too. In my opinion, the real problem and error is that the Hungarian soldiers expect and demand not only the ordinary payouts, but also the all-in victual and accommodation from the inhabitants, and under the pretext of this, they play tyrant over them, but cause the entire pauperization of the inhabitants..." But the inhabitants did not get into trouble with only the Hungarian soldiers, but also with the Imperial soldiers. The German garrison of Trnava threatened the Magistrate that if there is not enough food for them, they will take it from the city dwellers by force, and - if there will be a need - to seek after the food all over the countryside. The German mercenaries billeted in the Žitný ostrov also began to pillaging in the area. ${ }^{60}$

\footnotetext{
${ }^{59}$ MNL-OL C $770^{\text {th }}$ roll № 1149 , (ŠABB, Archive of the Koháry Family, Pars IV.), George Berényi's letter to Stephen Koháry (Dolné Obdokovce, $12^{\text {th }}$ of July, 1664).

${ }^{60}$ MNL-OL E $199,5^{\text {th }}$ box, $65^{\text {th }}$ pallium, fol. 166-167, Archivum familiæ Wesselényi (15831732), George Lippay's letter to Francis Wesselényi (Bratislava, $20^{\text {th }}$ of May, 1664).
} 
Encamped Imperial or Austrian soldiers also committed heavy abuses. In the beginning of April, some soldiers of the Brandenburg Troops caused several injuries and damages in almost all villages wherever they have been quartered. Their sins are so serious and shocking, so the Prince of Holstadt wanted the ringleaders to sentence to death, and gave the execution up only when Louis de Souches disapproved of it and exerted influence on him. ${ }^{61}$

The sabotage raids of the German and Hungarian soldiers paid by the Sovereign, and the free heyducks, would anger the Ottoman conquerors, and might exercise retaliations against the civil inhabitants. It is lit by the letter of complain of Nitra inhabitants dated from January 1664, that, in spite of the Turkish Garrison, several persons from the surrounding settlements had moved into the town. The raiders continuously bothered the so-increased inhabitants on their way, moreover, had penetrated to the town few days ago, and not only their belongings had taken or destroyed by them, but also they had taken captive soldiers from the Turkish Garrison. Hearing that, the Pasha of Buda felt indignant at the deed. He had travelled to Nové Zámky, then summoned and been dragged along the mayors of Nitra to him. The Pasha had threatened them, if once more the Hungarian soldiers would take Turkish soldiers captive from the Garrison or killed them, the mayors would be impaled and the male inhabitants over 4 years would be massacred. The Pasha ordered the mayors to write a letter to the competent Christian landlords and the authorities with a demand to put a check on the royal Hungarian soldiers, mainly the free heyducks, who would not pillage in Turkish occupied territories. ${ }^{62}$

If the abuses would be avoided, arrangements would be made in time. In March 1664, General Louis de Souches had wanted Hungarian border soldiers ("certo militis Præsidiarÿ") to billet into free royal town of Skalica as garrison. But the inhabitants of the town had been afraid of the heavy disagreement between them and the soldiers, so they had appealed to Francis Wesselényi that he interceded with Leopold the First on behalf of them and the before-mentioned soldiers would not be directed to their town. The Palatine agreed with the inhabitants of Skalica, and asked the Sovereign if the soldiers should be ordered to another place. ${ }^{63}$

\footnotetext{
${ }^{61}$ MNL-OL E $199,6^{\text {th }}$ box, $25^{\text {th }}$ pallium, fol. 2-3, Archivum familiæ Wesselényi (1583-1732), General Louis de Souches's letter to Francis Wesselényi (Trenčin, $5^{\text {th }}$ of April, 1664).

${ }^{62}$ MNL-OL E 199, $5^{\text {th }}$ box, $76^{\text {th }}$ pallium, fol. 8-9, Archivum familiæ Wesselényi (1583-1732), the letter of Nitra inhabitants to Francis Wesselényi (Nitra, 24 $4^{\text {th }}$ of January, 1664).

${ }^{63}$ MNL-OL E 199, $8^{\text {th }}$ box, $7^{\text {th }}$ sheaf, IV/2nd item, № 182, Francis Wesselényi's drafts to the Sovereign, Francis Wesselényi's letter to Leopold the First (Mosonszentmiklós, $21^{\text {st }}$ of March, 1664).
} 
The problems of the military provisions and payouts and their consequences ...

The lootings and cattle-lifts occurred on higher chance, when nonregistered - that is to say not encamped - soldiers made a dash at the settlements, as the encamped soldiers were ruled by military regulations and the abuses were strictly banned for them. Thus, the bigger part of the abuses was caused by the free heyducks and other, irregular vagrant and wandering soldiers. Stephen Koháry complained to the Palatine that free heyducks and "mischief, knave noblemen" committed several crimes in the name of his soldiers, moreover these rogues emphasized that they were belonged to the Palatine's troops in the effect of His recruiting patent. Koháry thought that the recruiting patent issued by the Palatine was not good solution at a long range, because Wesselényi had had good intentions in principle, when he had wanted to aggregate them under the banners, but the afore mentioned persons did not give up their criminal twist, and they choose the preying as main source of cost-of-living. So Koháry sent back this recruiting patent to the Palatine, and he apologized that his intention was not derived from his disrespect for the Palatine, but from the fact, that these free heyducks and other vagrant soldiers had not want to be registered by the administration of the regular (encamped) military troops, and as a consequence of it, they had not taken part in the Anti-Turkish military actions at all. Moreover, they worsened the anyway bad civil-military relationship conditions with their continuous crimes. Koháry added: of course, rascals could be found among the registered and encamped soldiers, for example, before few days ago, two men under the banner of Stephen Illésházy had escaped from their unit, driving "a plenty large enough cattle" off toward Trenčín. ${ }^{64}$

It might be a solution for the sake of the harmed owner, if the Palatine forbade the Magistrate of the mining towns and free royal towns to purchase the stolen cattle in their territory. Several cattle of the Koháry's demesne of Szécsény, sent to safeguard to Hont County, were driven off by soldiers belonging to Krupina Garrison about $7^{\text {th }}$ of June. They easily sold the animals in one of the mining towns, because the aldermen overlooked the origin of the animals, as he partook of the profit. Stephen Koháry thought so, that a strict forbidding would effectively deter the purchasing of the stolen cattle: the apprehension of the cattle-lifters would be easier, and the original possessor would get the animals back more quickly, as if they would be claimed back from the new owner, who also would arrogate them, as he paid the price for them. ${ }^{65}$

\footnotetext{
${ }^{64}$ MNL-OL E $199,4^{\text {th }}$ box, 61 $1^{\text {st }}$ pallium, fol. 13-14, Archivum familiæ Wesselényi (15831732), Stephen Koháry's letter to Francis Wesselényi (Vel'ké Uherce, 26 $6^{\text {th }}$ of May).

${ }^{65}$ MNL-OL E 200, $11^{\text {th }}$ sheaf, 32nd item, fol. 5-6, Acta Diversarum Familiarum 1527-1867, Stephen Koháry's letter to Francis Wesselényi (Imperial Camp by Levice, $10^{\text {th }}$ of June, 1664).
} 
If they could, the owners and land-stewards and other aldermen of the demesnes and possessions would ask Stephen Koháry's protection (as he was the Commander-in-Chief of the Hungarian troops) against the pillaging and depredating soldiers. Balthazar Egresdy asked his protection for the only one demesne near Strečno, because was overwhelmed by 400 or 500 mounted soldiers, who were continuously wasting all of his material and consumer goods. ${ }^{66}$ (Balthazar Egresdy had already appealed to Palatine Francis Wesselényi at the beginning of February, because Koháry's quartered soldiers had rendered impossible the living of his another village named Hliník nad Hronom with their forced demands. The Palatine asked Koháry to give up the further quarterage and he would not demand food from the villagers, either. ${ }^{67}$ ) At the time of the Siege of Nitra, a noblewoman Judy Zádory asked Koháry, if the siege would be successful, he would take charge of her house and mill situated in the town, and leave the soldier named George Malonyai with her female servant lived there. The noblewoman's further request was that if any cattle or horse of her remained after the siege, Koháry would not let them to be auctioned or looted by the soldiers, but if the looting had been already happened, she would go to the town, and recognize her own animals, and then Koháry would claimed them back from the soldiers for her. ${ }^{68}$ Stephen Matonyi on behalf of the Magistrate of Hlohovec asked Koháry, that the earlier billeted safeguard troops led by Francis Várady would leave for a longer time for the defence of the country town, and his favour would be remunerated by the Magistrate. ${ }^{69}$

We can find such cases when though the harmed person got his horse back by the order of Stephen Koháry, the soldiers took the horse from him again even before he could come home. The similar case was happened with one of the bondsmen of Sigismund Csáky from Jur nad Hronom on $24^{\text {th }}$ of June. ${ }^{70}$

\footnotetext{
${ }^{66}$ MNL-OL C 1294 $4^{\text {th }}$ roll, № 15413, (ŠABB, Archive of the Koháry Family, Pars V.), Balthasar Egresdy's letter to Stephen Koháry (Strečno Castle, $12^{\text {th }}$ of April, 1664).

${ }^{67}$ MNL-OL P 2257, 667 th unit, $5^{\text {th }}$ item, fol. 40, Correspondence of Stephen I. Koháry (16361664), Francis Wesselényi's letter to Stephen Koháry (Teplička nad Váhom, $4^{\text {th }}$ of February, 1664).

${ }^{68}$ MNL-OL C $1276^{\text {th }}$ roll № 12652, (ŠABB, Archive of the Koháry Family, Pars V.), Judita Zádory's letter to Stephen Koháry (Győr, 22 ${ }^{\text {nd }}$ of April, 1664).

${ }^{69}$ MNL-OL C $1298^{\text {th }}$ roll № 16271, (ŠABB, Archive of the Koháry Family, Pars V.), John Matonyi's letter to Stephen Koháry (Hlohovec, $3^{\text {rd }}$ of May, 1664).

${ }^{70}$ MNL-OL C $1276^{\text {th }}$ roll № 12605, (ŠABB, Archive of the Koháry Family, Pars V.), Sigismund Csáky's letter to Stephen Koháry (Levice, $26^{\text {th }}$ of June, 1664).
} 
The problems of the military provisions and payouts and their consequences ...

\section{Zhrnutie}

\section{Problémy so zásobovaním a financovaním armády a ich dôsledky počas vojenského t’aženia v Hornom Uhorsku v roku 1664}

Mad'arská historiografia sa pri opise uhorsko-osmanskej vojny v rokoch 1663 - 1664 doteraz sústred'ovala iba na najpodstatnejšie politicko-vojenské udalosti a iba v nepatrnej miere venovala pozornost' interpretácii udalostí, procesov a faktov, ktoré by nám umožnili pochopit' každodennost' tohto vojnového obdobia.

V prvej časti štúdie sú predstavené problémy logistiky a každodenného zásobovania armády v kampani, ktorá sa viedla na jar a v lete 1664, a to na základe archívnych zdrojov uložených $\mathrm{v}$ archíve rodiny Koháryovcov a rodiny Wesselényiovcov. Z dokumentov je zrejmé, že cisárska Vojenská rada začala bojové operácie takmer úplne bez príprav, a preto museli uhorské a nemecké jednotky zápasit's neustálym nedostatkom potravín a financií. Palatín František Wesselényi a jeho vyslanci neustále žiadali predstavitel'ov stolíc a banských komôr o obilie, jedlo a finančnú hotovost' na zaplatenie žoldu vojakom. Iba na základe ich obetavého (ale neviditel'ného) úsilia sa frontová línia na sever od Dunaja nezrútila. Aj ked' protiturecké sily mnohokrát zápasili s nedostatkom financií a potravín, napokon v závere vojny získali vít’azstvo.

Druhá čast' príspevku poukazuje na bežný jav vo vojenstve 17. storočia: na časté útoky ozbrojených osôb (nielen pravidelných vojakov) na civilné obyvatel'stvo a ich majetok. Je evidentné, že vojaci boli dohnaní k útokom pre svoju nespokojnost', ktorá vyplývala z absencie pravidelného žoldu a dodávok potravín. Častým priestupkom bola krádež dobytka, ktorý patril miestnemu obyvatel'stvu. Násilných činov sa však častejšie dopúšt’ali slobodní hajdúsi a potulní vojaci, ktorí neslúžili pod žiadnou zástavou. Aby zamedzili útokom na obyvatel'ov svojich panstiev, ich šlachtickí majitelia sa pokúšali žiadat' velitel'ov o ochranu svojho majetku (napríklad Štefana Koháryho). St'ažnosti a prosby o ochranu boli zasielané aj palatínovi, ktorý navrhoval, aby sa tieto problémy vyriešili zákazom náboru slobodných hajdúchov do armády a tiež zákazom zo strany mestských rád v slobodných král'ovských mestách nakupovat' vojakmi ukradnutý dobytok a kone. 